\title{
Methodological approaches to study of region's reproductive potential
}

\author{
Kasim Nazifovich Yusupov \\ Department of Macroeconomic Development \\ and State Governance \\ Bashkir State University, BSU \\ Ufa, Russia \\ kasim_jusupov@mail.ru
}

\author{
Rustem Rinatovich Akhunov \\ Department of Macroeconomic Development \\ and State Governance \\ Bashkir State University, BSU \\ Ufa, Russia \\ akhunov@list.ru
}

\author{
Azat Vazirovich Yangirov \\ Department of Macroeconomic Development \\ and State Governance \\ Bashkir State University, BSU \\ Ufa, Russia \\ jangirovav@list.ru \\ Yuliya Semenovna Toktamysheva \\ Department of Macroeconomic Development \\ and State Governance \\ Bashkir State University, BSU \\ Ufa, Russia \\ tokt-yuliya@yandex.ru
}

\begin{abstract}
The authors searched for ways of increasing a region's reproductive potential and enhancing its involvement in inter-regional and international division of labor. The study is based on simultaneous examination of a region as functional and structural subsystems of national economy by methods of quantitative and qualitative analysis. The paper presents theoretical assumptions and methodological foundations of research into the reproductive potential in the framework of regional economic management regarding resource, dynamic and resulting components. The authors developed a conceptual approach to study of the reproductive potential including three inter-related groups of potentials: resources, factors and results of economic development, which allows one to consider the complex of in-line, torque and dynamic parameters and to carry out assessment by means of a graphical model. The authors proposed an expanded view of an aggregate potential: a latent potential (implicit and unmeasured potential value); an actual potential (power and size of economic system); a forecasted potential (reserves and unused opportunities). The authors identified features of the reproductive potential (consistency, controllability, built-up capacity, variability of sizes and borders), which allow defining it as a major subsystem of regional regulation. The authors described features of the region's reproductive potential: its specific structure, dual focus of operation, a significant role of import and export.
\end{abstract}

Keywords—regional economics, region's reproductive potential, structure of reproductive potential

\section{INTRODUCTION}

Existing cross-sectoral and inter-regional studies consider a region's economy simultaneously from two perspectives: as functional and structural subsystems of national economy (the former regarded as a single organism with its own characteristics and the latter - as a stage in the taxonomic hierarchy of regions). This approach provides a basis for analysis and evaluation of all stages of the reproductive process. At the same time, it is evident that the product plays a crucial role as a link between all structures and proportions. Within this framework, the concept of "reproductive potential" is regarded as a subsystem of regional economic management. It has been established that its regulation has two dimensions: on the one hand, it involves management of the formation processes and, on the other hand implementation management. The general definition states that the reproductive potential is a set of resources, conditions (factors) and results of economic performance engaged in implementation of the reproduction process of the regional product and achievement of regional goals.

\section{METHODOLOGICAL FRAMEWORK}

\section{A. Principles of research into the structure of reproduction potential}

The concept of research into the region's reproductive potential comprises three groups of performance indicators. The first group is represented by resources in a pure form. These are naturally occuring and labour resources, fixed and circulating assets. Their basic feature is a measurement of torque (at a certain date). The resources are mostly indicative of economic opportunities in the first phase of the reproduction process, i.e. production. The second group includes factors (conditions of development) of reproductive potential, such as global price trends for energy resources, changes in supply and demand, as well as phases of the economic cycle. Factors in a market economy can represent a potential and may acquire capital form, generating income in various specific forms and creating opportunities for capital accumulation and increment. This group provides dynamic performance indicators. It equally impacts all phases of the reproductive process.

The third group consists of indicators showing the potential of attained economic performance - commissioning 
of fixed assets, investments in fixed capital, gross regional product, budget revenues and expenditures, export and import figures. The main feature of the group is in-line indicators (for a certain period), reflecting the contribution of an economic system makes in building-up the reproductive potential. They are related to the reproductive potential, as in the process of formation they become the so-called "derivative" resource, creating opportunities for further reproduction processes. The parameters of this group have a significant impact on the consumption phase of an economic system [13]. In particular, as a result of analysis of economic growth in large countries with an average income and substantial widely-used energy resources (Brazil, Russia, India, China, South Africa), Lechthaler F. has showed that the increased use of energy stimulates capital accumulation which in turn promotes economic growth [5].

For the purpose of studying the reproductive capacity as a complex of resources, factors and performance results, the authors have proposed the following classification with breakdown into three large groups.

1. The attained economic potential which describes the exploited opportunities in terms of actual volume and specific indicators. The strength and size (dimensions) of an economic system can be revealed through the following: a) actual (achieved) resource indicators: resources of explored mineral resources, population, labor force, cost of fixed production and non-production assets; b) actual (achieved) performance indicators: absolute figures of manufactured products and services, gross added value, different types of income; c) actual (achieved) performance factors: dynamic parameters of the potential, including resource and output indicators.

2. Projected economic reserves, opportunities for building up the above-mentioned three groups of indicators. For that matter, let us imply a possible, forecasted, potential-bearing, prospective potential which has not been used yet. This group also includes the far-reaching possibility of long-term intensive use of its constituents. This part of the potential may be exposed by such factors as estimated mineral reserves, amount of losses in the economy, the number and share of loss-making enterprises, the proportion of debt to payroll fund, the share of overdue payables, the number of unemployed and unemployment rate, the rate of inflation (they are the reason why actual figures lag behind specified rates).

3. The hidden (unevaluated) potential, which has an implicit, immeasurable, concealed nature and represents unmeasured values of the above-mentioned three groups of potential indicators (e.g. indicators of the "shadow economy"). This kind of the potential can be transferred to the first or second group as a result of subjective and objective changes in internal and external situation.

Using the above-stated methodological approach as a basis for investigation, the authors were able to elaborate and specify a general definition of the reproductive capacity for management purposes assuming it to be the complex of actual, forecasted and hidden resources, conditions (factors) and results of economic performance. With the aim to undertake more effective comparative analysis of the reproductive potential and to offer some visualization of it, the authors used the coordinate axes and built a rectangle (Fig. 1).

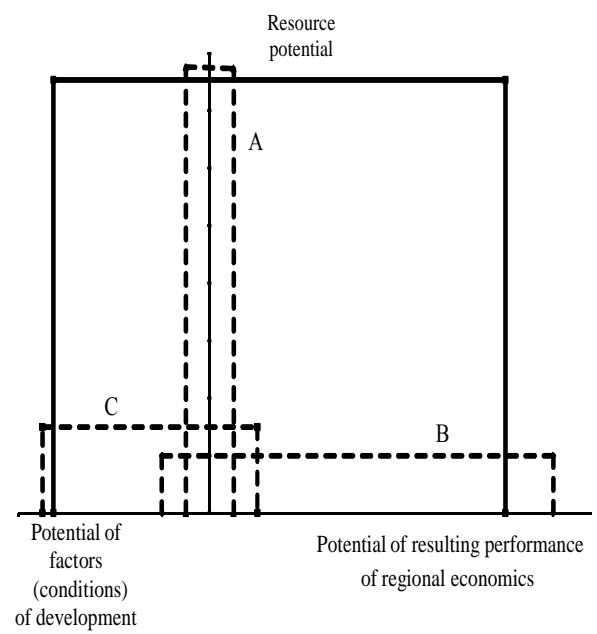

Fig. 1. Graphic representation of reproductive potential

It can take a variety of configurations depending on the degree of development of a certain element of the reproductive potential. A rectangle may be stretched upwards if the potential of resources is highly-developed (A) or it can be stretched to the right - thanks to high economic growth (B), or to the left - due to favorable market conditions (C). All the elements are closely linked. The degree of underdevelopment of one of the elements will have a negative impact on the quality, as well as on the mechanism of formation and use of the entire reproductive potential of the economic system.

Let us consider the main features of the region's reproductive potential. The most prominent feature of the potential under analysis is its consistency which is manifested in the fact that the reproductive potential can be viewed as a set of subsystems including natural resources, labor, investment, etc., interacting via inputs and outputs. . It has a focused and hierarchical structure, i.e. allows one to differentiate the lower and upper levels (for example, across territories), vertical and horizontal bonds as well. It has been noted that the region's reproductive potential affects the competitiveness of a region and the autonomy of development in the decentralization process [1].

Considering the reproductive potential as a regional management subsystem, one can not ignore the increasing degree of risk at the macro level. It is therefore of interest to study the relationship of regional risk and the reproductive potential if one seeks to build an effective regional development policy.

Adjustability is second essential feature. At the present stage, special attention is paid to the issue of the reproductive potential management which allows one to significantly improve the regional economic management system. The regional economic management system emerging in Russia is primarily aimed at managing the implementation of the reproductive potential and its extensive use. In order to 
overcome the imbalance of this approach to management of the reproductive potential, it is necessary to develop and strengthen its constituent elements. It should be mentioned that management activity will only be effective provided that the reproductive potential is understood as an integral and indivisible entity in the system of regional economic management.

The third feature is build up capacity. The regions face the acute problem of selecting, developing and building up strategic non-primary elements of the reproductive potential across industries, territories and sectors which are capable of providing long-term economic growth [3]. In this regard there appear to be two possible vectors of building up reproductive capacity - positive and negative, and two directions of economic development accordingly: predominant exploitation of the reproductive potential (negative vector) or prevailing formation or building up of the potential (positive vector).

The fourth feature of the reproductive potential is the presence of a subject component, which means an account of subjective elements in the use of the potential. The subject component refers to the ability of people to manage the elements of object component whereas the object component comprises resources and assets. This feature also affects the subjectivity of assessment of the reproductive potential, which is determined not only by completeness and accuracy of information base, but also by the approach of management entity to the reproductive potential. The subject component accounts for the fact that the value of the potential is not constant, and its size and boundaries are in constant motion.

\section{B. Specific aspects of studying reproductive potential at regional level}

The following features of the reproductive potential can be identified as a regional management subsystem: a specific structure of a region's reproductive capacity, its dual focus, peculiarities of export and import processes, particular patterns of inter-potential relations, asymmetric capacity across regions.

In order to assess the degree of autonomy of regional management, self-development opportunities in a region and achievement of regional interests, it is necessary to determine the internal (intrinsic) reproductive potential. The region's reproductive potential cannot be regarded as entirely regional, as, for instance, federal enterprises which are located in the region are a part of the federal reproductive potential. A significant share of the federal potential in a region can result in excessive dependence on the federal government and makes it difficult to manage this part of the regional potential [9].

In addition to this, the managing potential is getting more complicated due to the fact that expansion of capital from highly-developed entities (e.g. Moscow) has been observed in many regions [12]. This peculiarity enables us to identify in the overall reproduction potential and in its components a number of levels such as international, federal, different regional, common regional and local levels, according to the level of public administration (Fig. 2).

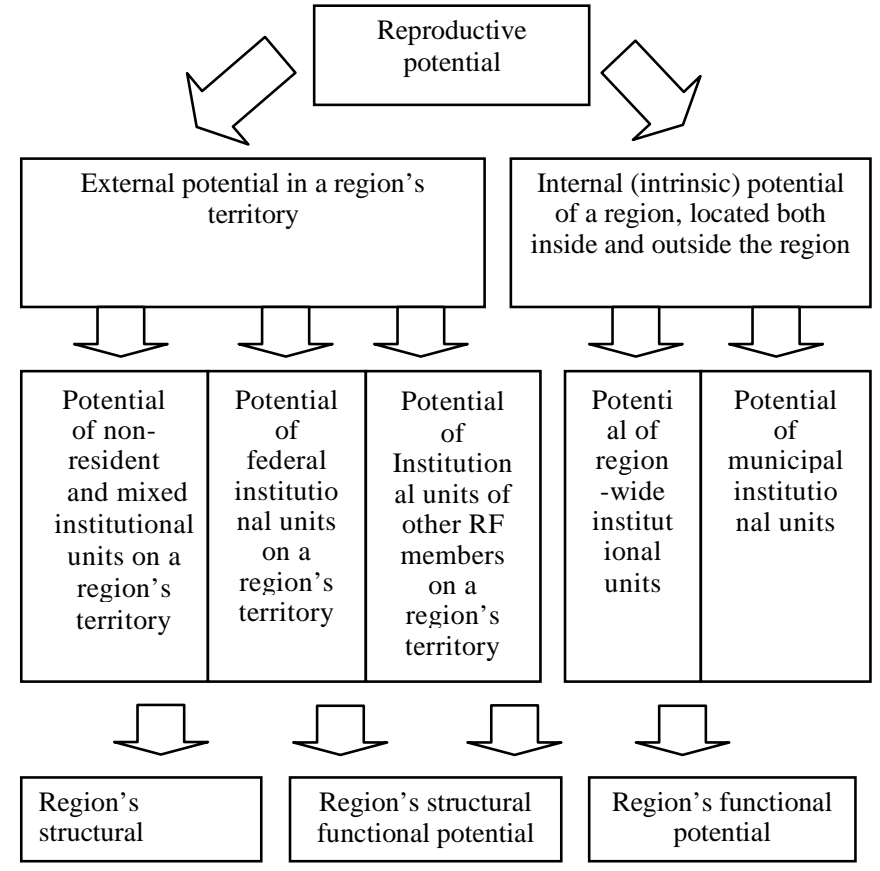

Fig. 2. Constituent elements of region's reproductive potential

Therefore, the internal (intrinsic) and external regional reproductive potentials may be found in a region. As a result, an appropriate balance between the identified components should be achieved in the regional economic management system.

One widely accepted point of view concerning the guidelines for regional economic development is the need to reduce intermediate product while building up final product of a region, which is thought to contribute to economic growth [4]. However, the proposed analysis is not entirely restricted by businesses and fixed assets. It can be applied to a number of categories including amounts of federal budget spent in a region, foreign investment and investments from other regions coming to a region, legal and illegal labor migration (both foreign and different regions). Anyway, regional development is determined by institutions existing in a country, current policy and ongoing economic development programs [7].

The dual focus of the reproductive potential is characterized by the fact that a region's economy operates within national economic system and the reproductive potential has a two-dimensional purpose of achieving both national and regional socio-economic goals. The balance of objectives can vary in different development periods. In periods of stronger power vertical, one can observe subordination of regional goals to national ones, and consequently, the reproductive potential is directed to satisfy the needs of a country whereas regional goals are likely to prevail in times of reinforced power horizontal.

The types of the regional reproductive potential under consideration can be represented by the following: a structural potential, i.e. capacity aimed at meeting the needs of an entire nation, which can primarily be exposed by export performance; functional capacity designed to address intra- 
regional needs; structural and functional capacity, i.e. the potential to satisfy both national and intraregional needs.

There are two groups of factors that determine formation of the strategic potential of regional economy. Firstly, factors that characterize socio-economic development, and secondly, resource factors [11]. In this case the main link between the two systems is gross regional product. So it has been proposed to carry out consistent assessment of the relationship of the first system indicators (i.e. indicators of socio-economic development) with the indicator of gross regional product, as well as indicators of the second system (i.e. resources and the potential of a region) also with an indicator of gross regional product [2].

Regional economy involves transfer of some elements of the reproductive potential due to the following: 1) reproductive potential is a system, and any system has input and output channels, that is import and export; 2) there is import and export of resources, factors (e.g. imported inflation) and performance results (e.g. goods and services), which were presented above as constituent elements of the reproductive potential.

\section{Quantitative evaluation of region's reproduction potential}

In view of the above-mentioned information, general formula for movements of the reproductive potential, its elements are stated as follows:

$$
Q p t_{1}=Q p t_{0}+(V p t+I p t)-(P p t+E X p t),(1)
$$

where $Q p t_{1}$ - region's aggregate reproductive potential at the end of the current year; $Q p t_{0}$ - region's aggregate reproductive potential at the beginning of the current year; $V p t$ - region's contribution to the increase of its reproductive potential; Ipt - transfer to the region of some elements of the reproduction potential from external sources (i.e. other regions, national and world economy) for the year; Ppt consumption of the reproductive potential in the region for the year; EXpt - reallocation of region's reproductive potential elements from the region to external environment for the year.

Certain components of the equation may be absent altogether or be displayed in a different way for individual elements of region's reproductive potential. For example, Vpt element will be absent for mineral resources, since it is impossible to produce this type of resource, otherwise new explored reserves will be included in it. Ipt and EXpt values will not be applicable for fixed assets with regard to buildings and facilities due to their property of capital asset. As for the ecological potential, it may be noted that in case the manufacture of exported products causes serious nature pollution, the region will actually be exporting (EXpt) its ecological potential. It has been shown in some studies that there is not only a close relationship between investment and innovation, but also some impact of these indicators on the volume of gross regional product, regional exports, unemployment and inflation [10]. The result expected from innovation is technological efficiency of entire industries.

In order to identify specific features of inter-potential linkages, the authors have considered the most significant dependence of gross regional product as a major indicator of implementation of the reproductive potential on formation indicators.

As a result, the authors managed to identify regions with "wrong" linkages, in other words, contradictory to existing economic laws. For example, when evaluating the impact of the number of employed population on industrial production index, correlation coefficient of less than 0.5 was recorded for 12 regions of the Russia, i.e. an increase in the number of employed people led to decline in industrial production index.

The asymmetry of the potential across regions is represented by the estimated differentiation of indicators which show formation and implementation of the reproductive potential of Russian regions. It has been concluded that potential formation indicators have large dispersal values compared with variations in the main measure of implementation of the reproductive potential, i.e. gross regional product, calculated in specific terms.

In the authors' opinion, it is possible take two approaches to developing analytical tools for management of the reproductive potential. The first approach regards the reproductive potential as a single indivisible whole, a characteristic of economic capacity; and the potential is understood to be economic strength, power of economic processes or systems. The reproductive potential as a single category measured by one or two integrated indicators. The most widely-accepted indicators at the regional level are as follows: absolute figures of gross national product and national income, as well as their per capita values for conditions of planned economy, and overall figures of gross regional product and per capita values for conditions of market economy.

The second approach investigates individual components of the reproductive potential. However, a number of problems arise in this connection. Let us suppose that the first issue is concerned with cost calculation of the reproductive potential by means of summing up values of elements which are measured by mixed-level indicators. The authors have worked out eight measurements for reproductive potential elements:

- direct absolute indicators (natural resources in tonnes, cubic meters; labor force, number of persons);

- maximum gross regional product, which can be produced with full capacity of the potential (this calculation may be applied to natural resources);

- a market price of resources (also natural resources);

- annual gross regional product, with complete utilization of a resource (for example, Okun's law on the statistical relationship between a country's unemployment rate and the growth rate of its economy);

- current annual rates (e.g., government expenditures, investment and environmental expenses, output of certain types of products in measurement of a range of potentials innovation, investment, tax, environmental); 
- indicative parameters and indexes, with vector rather than dimensional nature (for example, the measuring human potential);

- shares, growth rates, percentages (for instance, a share of knowledge-intensive products in total output is taken into consideration in calculations of the innovation potential);

- forecasted indicators (for example, revenue forecast is used in calculations of the tax potential).

The second major issue concerning total estimate of the reproductive potential is overlapping of performance indicators: often one indicator is applicable to a number of potentials. For example, the volume of investments, which shows the region's investment potential, is at the same time an integral part of gross regional product, which describes the production potential.

The third issue is found in incorrect summation of torque and in-line indicators, which even occurs in methodology of national accounting systems in calculation of national wealth, when value of fixed assets (acumulated or torque value) and cost of working capital (annual, current or in-line component) are added up.

But these problems are not supposed to provide grounds to give up attempts to provide consolidated assessment of the reproductive potential. In the authors' opinion, multidimensional nonparametric methods of statistical analysis, which make use of relative estimation, continue to remain one of the most appropriate approaches. It appears that the most preferable technique is the method of relative difference, which has received worldwide acceptance for calculating the Human Development Index, which has been published every year in the United Nations special report since 1990.

The relative difference method involves obtaining estimates for particular performance indicators by means of rating using an estimation formula (2). That means the exceeding value of $j$-th particular index for $i$-th region over the minimum value corresponds to the scale of variation of $j$-th particular index across the entire set of regions. Index values $t_{i j}$ will belong to the domain $[0,1]$. For the region with the worst value $t_{\mathrm{ij}}$ is equal to zero, while with the best value - 1 .

$$
\mathrm{t}_{\mathrm{ij}}=\frac{\mathrm{x}_{\mathrm{ij}}-\mathrm{x}_{\mathrm{jmin}}}{\mathrm{x}_{\mathrm{jmax}}-\mathrm{x}_{\mathrm{jmin}}}
$$

According to the United Nations methodology an integral indicator is calculated as the geometric mean of particular indicators. It seemed that a more convenient way to obtain the value of integral is by using simple arithmetic mean of the particular coefficients according to the formula (3). In this case $T_{i}$ ratio values will also belong to the domain $[0 ; 1]$. The case $T_{i}=1$ can only be achieved if the $i$-th region has the best possible values for all partial parameters.

$$
T_{i}=\frac{\sum_{j=1}^{n} t_{i j}}{n}
$$

\section{FACTOR ANALYSIS AND DISCUSSION}

The methodology described above has been applied to measure and assess the reproductive potentials of regions of the Volga Federal District of the Russian Federation in terms of the labor potential and integral characteristic [14].

The demographic situation in the regions of the Volga Federal District is characterized by more serious negative trends than the reproduction of Russian population on the whole. The vast majority of regions in the district, with the exception of Bashkortostan and Tatarstan, demostrate decreasing migration which fail to compensate for natural population decline. As a result, the population tends to dwindle.

Currently total population growth in the Russia is estimated at +2.1 persons per 1 thousand people, while in the Volga Federal District this figure is negative (-0.8). The oscillation range within the district is rather significant: from 4.4 in Tatarstan to -5.0 in the Kirov region. The highest negative value of natural increase in 2014 is observed in the Mordovia, Kirov, Orenburg, Penza and Ulyanovsk regions. The highest net migration outflow was observed in the same year in such areas as Orenburg (-4.1) and Kirov (-2.7) regions, Mari El and Chuvashia (-2.8 and -2.1 respectively). Due to significant net migration inflows the situation with population decline in the Samara region and Tatarstan is considerably mitigated.

Let us propose the following albeit conventional method as one of the methods for assessing the labor potential. Manpower can be represented as a commodity whose consumption per month with full employment of labor force may be calculated as follows: average salary per employee multiplied by the number of persons in the labor force. Accordingly, in order to calculate this ratio for the year the figure must be multiplied by 12 months. Presumably, this commodity is completely worn out during $n$ years. Conventionally, one can take the following value. The working life of a male is 43 years (59-16); the working life of a female is 38 years (54-16). Therefore, $n$ can be taken as the arithmetic mean of 43 and 38 , which equals 40.5 years. This commodity will have a $2,469 \%$ wear or depreciation annually or in terms of value: average salary per employee multiplied by the number of persons in the labor force, multiplied by 12 months. The resulting formula for estimation of the labor potential may be as follows:

$$
\mathrm{Q}_{\mathrm{tr}}=\frac{\mathrm{S}_{\mathrm{s}} \cdot \mathrm{q}_{\mathrm{tr}} \cdot 12}{0,02469}=\mathrm{S}_{\mathrm{s}} \cdot \mathrm{q}_{\mathrm{tr}} \cdot 486,03
$$

where $Q_{\text {tr }}$ - value of labor force; $S_{S}$ - average monthly wage per employee in a region; $\mathrm{q}_{\mathrm{tr}}$ - number of labor resources in a region, persons. All values are calculated at a certain date (for example, at the beginning of the year).

Using this formula, the authors have performed a pilot calculation of the labor potential with respect to the Volga Federal District in 2014 (Table. 1). Due to complicated access to labor force statistics for the Russian regions, when making calculations, the authors used data of economically active 
population in the region. The table shows that in terms of the labor potential estimated by the above-mentioned method, the leading positions are occupied by such regions as Tatarstan, Bashkortostan, Samara and Nizhny Novgorod regions. The lowest ranking is observed for Penza region and the Mordovia and Mari El. In 2014, the gap between the maximum and minimum values was 6.3 times (in 2005 - 7.2 times).

TABLE I. ESTIMATION OF LABOR POTENTIAL OF THE Volga FEDERAL DISTRICT REGIONS

\begin{tabular}{|c|c|c|c|c|c|c|}
\hline & $\begin{array}{c}\text { Labor } \\
\text { potential } \\
\text { in 2005, } \\
\text { bln } \\
\text { rubles }\end{array}$ & $\begin{array}{c}\text { Region's } \\
\text { rating } \\
\text { by } \\
\text { volume } \\
\text { of labor } \\
\text { potential } \\
\text { in 2005 }\end{array}$ & $\begin{array}{c}\text { Labor } \\
\text { in 2008, } \\
\text { bln } \\
\text { rubles }\end{array}$ & $\begin{array}{c}\text { Region's } \\
\text { rating } \\
\text { by } \\
\text { volume } \\
\text { of labor } \\
\text { potential } \\
\text { in 2008 }\end{array}$ & $\begin{array}{c}\text { Labor } \\
\text { intential } \\
\text { in }\end{array}$ & $\begin{array}{c}\text { Region's } \\
\text { bln } \\
\text { rubles } \\
\text { rating } \\
\text { by } \\
\text { volume } \\
\text { of labor } \\
\text { potential } \\
\text { in 2014 }\end{array}$ \\
\hline $\begin{array}{c}\text { Russian } \\
\text { Federation }\end{array}$ & 307.17 & - & 636.6 & - & 1191 & - \\
\hline $\begin{array}{c}\text { Volga Federal } \\
\text { District }\end{array}$ & 49.6 & - & 102 & - & 185.3 & - \\
\hline $\begin{array}{c}\text { Republic of } \\
\text { Bashkortostan }\end{array}$ & 6.49 & 2 & 13.9 & 2 & 24 & 2 \\
\hline $\begin{array}{c}\text { Republic of } \\
\text { Mari El }\end{array}$ & 0.91 & 14 & 1.9 & 14 & 3.6 & 14 \\
\hline $\begin{array}{c}\text { Republic of } \\
\text { Mordovia }\end{array}$ & 1.07 & 13 & 2.4 & 13 & 4.5 & 13 \\
\hline $\begin{array}{c}\text { Republic of } \\
\text { Tatarstan }\end{array}$ & 6.45 & 3 & 14.3 & 1 & 28.3 & 1 \\
\hline $\begin{array}{c}\text { Udmurt } \\
\text { Republic }\end{array}$ & 2.54 & 9 & 5 & 8 & 9.4 & 8 \\
\hline $\begin{array}{c}\text { Chuvash } \\
\text { Republic }\end{array}$ & 1.63 & 12 & 3.7 & 11 & 6.9 & 9 \\
\hline Perm Krai & 3 & 8 & 10.4 & 5 & 16.9 & 5 \\
\hline Kirov region & 4.99 & 4 & 4.2 & 9 & 6.9 & 10 \\
\hline $\begin{array}{c}\text { Nizhny } \\
\text { Novgorod } \\
\text { region }\end{array}$ & 3.36 & 7 & 11.8 & 4 & 22 & 4 \\
\hline Orenburg region & 2.14 & 10 & 6.1 & 7 & 11.9 & 7 \\
\hline $\begin{array}{c}\text { Penza region } \\
\text { region }\end{array}$ & 3.59 & 5 & 4 & 10 & 7.7 & 12 \\
\hline $\begin{array}{c}\text { Samara region } \\
\text { a. Soratov region }\end{array}$ & 6.52 & 1 & 12.7 & 3 & 22.1 & 3 \\
\hline Ulyanovsk & 1.81 & 11 & 3.7 & 12 & 6.7 & 11 \\
\hline Sores & & 6 & 7.7 & 6 & 13.5 & 6 \\
\hline
\end{tabular}

Source: authors' calculations based on data obtained from Russian Federal State Statistics Service

Basically, if the effectively regulated labor potential can provide qualitative and quantitative shifts in the entire system of reproductive capacity. However, the investment potential is likely to make a far more substantial contribution to these processes. The authors have subjected the region's investment potential to treating as a crucial element of the reproductive potential. Foreign investment, knowledge and imported goods greatly contribute to generation of innovation. They are also playing an increasingly more important role as an innovative stimulus for neighboring areas with a spatial spillover effect. At the same time, the depth and breadth of knowledge and expertise gained through specialization and diversification of the economy affects the progress of innovation [6].

Let us consider one of the most important indicators of the achieved investment potential - investment in fixed assets in the regions of the Volga Federal District (Table 2.).

TABLE II. VOLUME OF INVESTMENTS IN FIXED CAPITAL ASSETS ACROSS REGIONS OF THE VOLGA FEDERAL DISTRICT IN 2014

\begin{tabular}{|c|c|c|c|c|c|c|c|}
\hline \multirow[t]{4}{*}{ Regions } & \multirow{4}{*}{$\begin{array}{c}\text { mln. } \\
\text { rubles }\end{array}$} & \multicolumn{6}{|c|}{ in \% to cumulative investment in fixed assets } \\
\hline & & \multirow{3}{*}{$\begin{array}{l}\text { propri } \\
\text { etary } \\
\text { funds }\end{array}$} & \multirow{3}{*}{$\begin{array}{c}\text { funds } \\
\text { attract } \\
\text { ed }\end{array}$} & \multicolumn{4}{|c|}{ including from attracted funds } \\
\hline & & & & \multirow{2}{*}{$\begin{array}{c}\text { bank } \\
\text { 's } \\
\text { loans }\end{array}$} & \multirow{2}{*}{$\begin{array}{c}\text { budg } \\
\text { et } \\
\text { fund } \\
s\end{array}$} & \multicolumn{2}{|c|}{$\begin{array}{c}\begin{array}{c}\text { including funding } \\
\text { from }\end{array} \\
\end{array}$} \\
\hline & & & & & & $\begin{array}{l}\text { federal } \\
\text { budget }\end{array}$ & $\begin{array}{c}\text { budgets of } \\
\text { RF } \\
\text { members }\end{array}$ \\
\hline $\begin{array}{c}\text { Russian } \\
\text { Federation }\end{array}$ & 13557515 & 45.8 & 54.2 & 10.6 & 17.0 & 9.1 & 6.4 \\
\hline $\begin{array}{c}\text { Volga Federal } \\
\text { District }\end{array}$ & 2355973 & 53.3 & 46.7 & 13.4 & 12.8 & 6.2 & 5.5 \\
\hline $\begin{array}{c}\text { Republic of } \\
\text { Bashkortostan }\end{array}$ & 285520 & 55.8 & 44.2 & 12.3 & 16.8 & 6.7 & 9.1 \\
\hline $\begin{array}{c}\text { Republic of } \\
\text { Mari El }\end{array}$ & 48354 & 54.2 & 45.8 & 23.2 & 16.1 & 5.1 & 10.0 \\
\hline $\begin{array}{c}\text { Republic of } \\
\text { Mordovia }\end{array}$ & 55292 & 29.9 & 70.1 & 17.6 & 35.7 & 18.1 & 14.6 \\
\hline $\begin{array}{c}\text { Republic of } \\
\text { Tatarstan }\end{array}$ & 542781 & 61.3 & 38.7 & 13.9 & 10.9 & 4.7 & 5.9 \\
\hline $\begin{array}{l}\text { Udmurt } \\
\text { Republic }\end{array}$ & 89836 & 51.7 & 48.3 & 3.5 & 20.1 & 11.8 & 6.2 \\
\hline $\begin{array}{l}\text { Chuvash } \\
\text { Republic }\end{array}$ & 56446 & 36.2 & 63.8 & 9.8 & 30.6 & 15.8 & 12.7 \\
\hline Perm Krai & 185649 & 67.0 & 33.0 & 8.4 & 7.6 & 3.3 & 2.7 \\
\hline Kirov region & 56294 & 40.5 & 59.5 & 22.0 & 15.1 & 7.2 & 5.6 \\
\hline $\begin{array}{l}\text { Nizhny } \\
\text { Novgorod } \\
\text { region }\end{array}$ & 286619 & 48.4 & 51.6 & 18.7 & 15.2 & 8.8 & 4.4 \\
\hline $\begin{array}{l}\text { Orenburg } \\
\text { region }\end{array}$ & 150208 & 67.0 & 33.0 & 10.6 & 6.7 & 2.4 & 3.7 \\
\hline Penza region & 83690 & 28.3 & 71.7 & 18.3 & 18.1 & 9.4 & 6.9 \\
\hline Samara region & 300311 & 50.4 & 49.6 & 15.2 & 9.8 & 4.2 & 4.7 \\
\hline Saratov region & 132804 & 38.9 & 61.1 & 11.6 & 8.8 & 5.8 & 1.9 \\
\hline $\begin{array}{l}\text { Ulyanovsk } \\
\text { region }\end{array}$ & 82168 & 35.2 & 64.8 & 6.7 & 13.6 & 11.3 & 1.8 \\
\hline
\end{tabular}

Source: authors' calculations based on data obtained from Russian Federal State Statistics Service

According to the table, the largest volumes of investments are recorded in the Republics of Tatarstan and Bashkortostan, Samara and Nizhny Novgorod regions, and Perm Krai. In general, the main source of financing investment in the Volga Federal District was equity capital of enterprises, which accounted for $53.3 \%$ of the total investment in fixed assets. A number of regions, such as the Republics of Mordovia, Udmurtia, Chuvashia and Penza region, are characterized by the biggest share of budget funds in investments $(25 \%$ and above). These regions show a low level of investment. On the contrary, regions with high volumes of investment display a low share of budget funds in attracted finance. In particular, 
this figure does not exceed $10 \%$ in Samara, Saratov, Orenburg regions and Perm Krai.

Zemtsov S.P. and Baburin V.L. carried out their own calculations to assess the effect of the economic-geographical position (EGP) on regional development which revealed significant spatial differentiation of development for various Russian territories. The regions located in the proximity of Moscow and St. Petersburg have a maximum inter-regional potential of EGP, and this indicator is steadily decreasing from west to east [15]. Savelyeva M.V. referred to these regions as "growth engines". They exert some influence on the development of other Russian regions by encouraging the development of related and complementary sectors in the neighboring regions, development of infrastructure, enhanced innovative processes and multidimensional effects [8].

These particular indicators of the potential have been processed by the "Pattern" technique that allows one to assess these indicators by means of correlating the actual values with the best possible ones (Fig. 3).

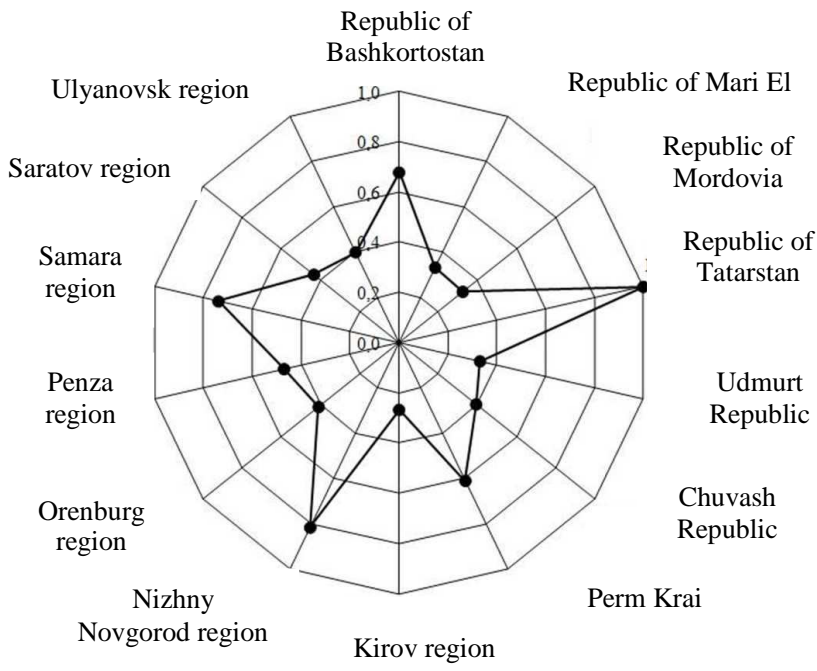

Fig. 3. Aggregate reproductive potential of Volga Federal District

The integral coefficient (I) can take values between 0 and 1 , consequently, it is possible to organize regions into groups to distinguish five groups of regions at regular intervals:

Group 1 - very high level of the potential: $0.8<\mathrm{I} \leq 1$ : in 2015 - Tatarstan; in 2014 - Tatarstan and Nizhny Novgorod region; in 2008 - Republics of Tatarstan and Bashkortostan, Nizhny Novgorod and Samara regions, Perm Krai.

Group 2 - high level of the potential: $0.6<\mathrm{I} \leq 0.8$ : in 2015 - Bashkortostan, Samara region; in 2014 -Bashkortostan, Samara region, Perm Krai (there were no division into regions in 2008).

Group 3 - average level of the potential: $0.4<\mathrm{I} \leq 0.6$ : in 2015 - Nizhny Novgorod region, Perm Krai; in 2014 Orenburg, Penza, Saratov, Ulyanovsk regions; in 2008 Saratov, Penza, Orenburg, Ulyanovsk regions, Chuvash and Udmurt Republics.
Group 4 - low level of the potential: $0.2<$ I $\leq 0.4$ : in 2015 - Orenburg, Penza, Saratov, Ulyanovsk, Kirov regions, Chuvash and Udmurt Republics; in 2014 - Mari El, Mordovia, Udmurt and Chuvash, Kirov region; in 2008 - Mordovia and Mari El and Kirov region.

Group 5-extremely low level of the potential: $0 \leq \mathrm{I} \leq 0.2$ : such regions were not found in the Volga Federal District.

\section{CONCLUSION}

The findings of the research suggest that the region's reproductive potential is an objective economic category, which is defined as a system with mutually conditioned, interrelated, and interdependent subsystems and elements. Identification of the whole system, its subsystems and components has become possible thanks to the methodology, which includes methods of determining the nature of the potential, its quantitative and qualitative measurements, classifications, analysis and assessment of various potentials. Scientific rationale of the methodology for analyzing the regional reproduction potential is needed to identify problems and focus of action in dealing with two related objectives: meeting national needs, contribution to the potential of national economy and internal expanded reproduction, regional integrated development.

The concept of the study is based on the identification in the structure of the region's reproductive potential the following categories: category of resources, factors (conditions) of development, performance results. The reproductive potential can be considered as a continuously evolving subsystem of regional economic management, in which transition to the next state depends on varying parameters of resources, factors and results. Potential's elements can be examined on the basis of division into the following groups: 1) actually achieved and used potential which is disclosed by means of indicators reached at a certain point; 2) estimated but not used potential which is characterized by indicators of economic reserves; 3) hidden immeasurable potential, which cannot be measured because of lack of access to information and appropriate conditions.

The reproductive potential can be characterized by such features as systematic and objective formation, different degrees of investigation in periods of planned and market economy; adjustability and controllability of its formation; build up capacity, which entails the problem of transition to development with the scalable reproductive potential; continuous variability of parameters due to subjective component.

The research allowed identifying a number of features that distinguish the management of the region's reproductive potential from the management of the reproductive potential of the national economy. The authors have determined the following main regional features: a specific structure of the potential due to available in the region external (foreign, federal, different regional) and internal (region-wide, municipal) sources of the potential; focus of operation primarily on satisfaction of national needs (structural orientation) or intra-regional needs (functional orientation) or mixed orientation (structural and functional); a significant role 
of import and export in the formation of the reproductive potential.

On the basis of the system of methods, the authors have elaborated methodology for analysis of a region's reproductive potential which includes two areas: research methodology of the reproductive potential as a whole with the help of concise integrated indicators and analysis by means of division into individual components.

To sum up, the reproductive potential objectively is an important fundamental subsystem of regional economy, and its comprehensive analysis is intended to be crucial in the implementation of both day-to-day and strategic regional management. This is due to the fact that, on the one hand, the growth rate and the proportions of a region's economy are determined by level and efficient use of the reproductive potential, and on the other hand, the reproductive potential is an aggregated result, outcome of performance, which is a stage for further regional development.

\section{Acknowledgment}

The work was performed with the financial support of the grant "Regional Contest "Ural: history, economy, culture" 2016 - Respublika Bashkortostan", No 16-12-02011, of the Russian Foundation for Basic Research.

\section{References}

[1] M. Arzaghi, J. V. Henderson, "Why countries are fiscally decentralizing", Journal of Public Economics, vol. 89, pp. 1186-1188, 2005.

[2] D.A. Durdyeva, O.L. Taran, D.I. Aslanov, N.A. Bindasova, M.I Borlakova, "Assessment and analysis of resource approach to formation of strategic potential of economy of the region", International Review of Management and Marketing, vol. 1, pp. 84-89, 2016.

[3] O. Kazakova, N. Kuzminykh, "Prospects of development of agrotourism in the regional economy", SGEM2015 Conference Proceedings, Book 2, Vol. 3, 683-690 pp., August 26 - September 012015
[Proceedings of International Multidisciplinary Scientific Conferences on Social Sciences and Arts, p.1038, 2015].

[4] G. Krumins, I. Krumina, S. Rozentale, "Preconditions for regional economic growth at the district level in Vidzeme, Latvia", Procedia Social and Behavioral Sciences, vol. 213, pp. 117-122, 1 December $2015\left[20^{\text {th }}\right.$ International Scientific Conference Economics and Management 2015 (ICEM-2015), p. 1068, 2015].

[5] F. Lechthaler, "Economic growth and energy use during different stages of development: An empirical analysis", Environment and Development Economics, vol. 1, pp. 26-50, 2017.

[6] T. Li, W. Fu, "Spatial processes of regional innovation in Guangdong province, China: Empirical evidence using a spatial panel data model", Asian Journal of Technology Innovation, vol. 3, pp. 304-320, 2015.

[7] D. Mackinnon, "Book review: governing local and regional economies: institutions, politics and economic development", European Urban and Regional Studies, vol. 2, pp. 181-183, 2006.

[8] M.V. Savelyeva, "Regions that are the "Locomotives of growth: their essence and criteria", Asian Social Science, vol. 7, pp. 66-73, 2015.

[9] N. Z. Solodilova, R. I. Malikov, K. E. Grishin, "Development of the tools for the assessment of the influence of administrative regulation on the business efficiency in the region", Economy of region, vol. 12, issue 4, pp. 1001-1013, 2016.

[10] V. A. Strat, A. R. Danciu, "A regional level hierarchy of the main Foreign Direct Investments' Determinants-Empirical study, the case of Romanian manufacturing sector", Procedia Social and Behavioral Sciences, vol. 181, pp. 321-330, May 2015 [3rd International Conference on Leadership, Technology and Innovation Management, p. 430, 2015].

[11] I. Turgel, L. Bozhko, L. Leskova, "State support of monotowns in Russia and Kazakhstan: Experience and Problems", Energy Procedia, vol: 95, pp. 559-563, September 2016 [International Scientific Conference on Environmental and Climate Technologies, CONECT 2015, p. 568, 2016].

[12] Y. Vertakova, Y. Polozhentseva, M. Klevtsova, "The Formation of the Propulsive Industries of Economic Development Acting as the Growth Poles of Regions", Procedia Economics and Finance, vol. 24, pp. 750 759, 2-4 July 2015 [International Conference on Applied Economics, ICOAE 2015, p. 784, 2015].

[13] K. N. Yusupov, R. R. Akhunov, Y. S. Toktamysheva, "Assessment of innovative effect of national and regional economics", Statistics and Economics, vol. 3, 164-168, 2013.

[14] K.N. Yusupov, A.R. Taimasov, A.V. Yangirov, R.R. Akhunov, Region in the system of national economy, Ufa: Publishing center of BashGU, 2005.

[15] S.P. Zemtsov, V.L. Baburin, "Assessing the potential of economicgeographical position for Russian regions", Economy of Region, vol. 1, pp. 117-138, 2016. 